\section{BRAZIULAN JOURNAL \\ OF MEDICAL AND BIOLOGICAL RESEARCH}

www.bjournal.com.br
ISSN 1414-431X

Volume 45 (12) 1102-1340 December 2012

\section{BIOMIDICAL SCIENCES}

AND

CLINICAL INVESTIGATION

Braz J Med Biol Res, December 2012, Volume 45(12) 1284-1286

doi: 10.1590/S0100-879X2012007500154

High sensitivity C-reactive protein distribution in the elderly: the Bambuí Cohort Study, Brazil

L.G.S. Assunção, S.M. Eloi-Santos, S.V. Peixoto, M.F. Lima-Costa and P.G. Vidigal

The Brazilian Journal of Medical and Biological Research is partially financed by

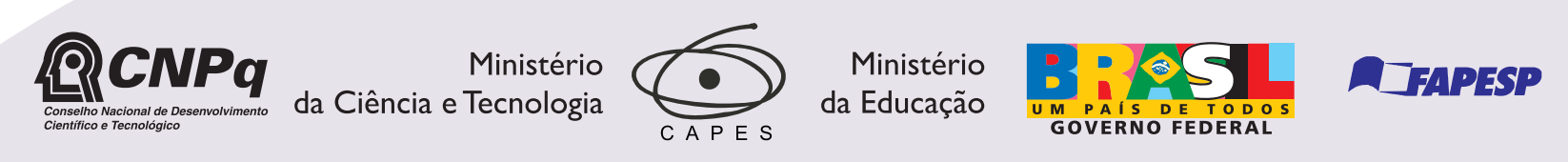

Sciefo
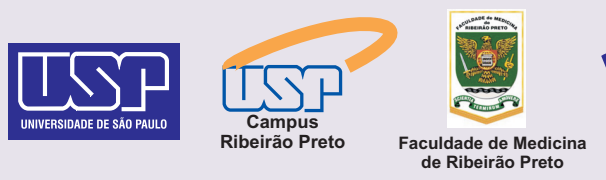

Institutional Sponsors

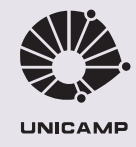

SHIMADZU

$\oplus$ UNICAMP

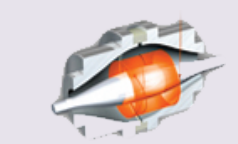

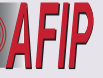

Associaçaco Associaçăo
Fundo
de Incentivo de Incentivo
à Pesquisa 


\title{
High sensitivity C-reactive protein distribution in the elderly: the Bambuí Cohort Study, Brazil
}

\author{
L.G.S. Assunção ${ }^{1}$, S.M. Eloi-Santos ${ }^{1,2}$, S.V. Peixoto ${ }^{3,5}$, M.F. Lima-Costa ${ }^{4,5}$ \\ and P.G. Vidigal ${ }^{1,2}$ \\ ${ }^{1}$ Programa de Pós-Graduação em Patologia, Faculdade de Medicina, \\ Universidade Federal de Minas Gerais, Belo Horizonte, MG, Brasil \\ 2Departamento de Propedêutica Complementar, Faculdade de Medicina, \\ Universidade Federal de Minas Gerais, Belo Horizonte, MG, Brasil \\ ${ }^{3}$ Departamento de Enfermagem Aplicada, Escola de Enfermagem, \\ Universidade Federal de Minas Gerais, Belo Horizonte, MG, Brasil \\ ${ }^{4}$ Departamento de Medicina Preventiva e Social, \\ Universidade Federal de Minas Gerais, Belo Horizonte, MG, Brasil \\ ${ }^{5}$ Centro de Pesquisas René Rachou, Fundação Oswaldo Cruz, Belo Horizonte, MG, Brasil
}

\begin{abstract}
The measurement of the serum concentration of the acute-phase reactant C-reactive protein (CRP) provides a useful marker in clinical practice. However, the distribution of CRP is not available for all age and population groups. This study assessed the distribution of high sensitivity CRP (hs-CRP) by gender and age in 1470 elderly individuals from a Brazilian community that participates in the Bambuí Cohort Study. Blood samples were collected after $12 \mathrm{~h}$ of fasting and serum samples were stored at $-70^{\circ} \mathrm{C}$. Measurements were made with a commercial hs-CRP immunonephelometric instrument. More than $50 \%$ of the results were above $3.0 \mathrm{mg} / \mathrm{L}$ for both genders. Mean hs-CRP was higher in women $(3.62 \pm 2.58 \mathrm{mg} / \mathrm{L})$ than in men $(3.03 \pm 2.50 \mathrm{mg} / \mathrm{L})$. This difference was observed for all ages, except for the over-80 age group. This is the first population-based study to describe hs-CRP values in Latin American elderly subjects. Our results indicate that significant gender differences exist in the distribution of hs-CRP, and suggest that gender-specific cut-off points for hs-CRP would be necessary for the prediction of cardiovascular risks.
\end{abstract}

Key words: C-reactive protein; Elderly; Epidemiology; Cardiovascular risk; Brazil

\section{Introduction}

Epidemiological surveys that estimate the prevalence of diseases and risk factors contribute to a general and particular analysis of the study population. Several studies have shown that high sensitivity C-reactive protein (hs-CRP) is of interest in predicting the risk of future cardiovascular disease $(1,2)$. Determination of the distribution of hs-CRP in elderly people is also of interest for clinicians in screening for inflammatory diseases and monitoring the response to therapy. Although the available data indicate that genderspecific cut-off points for hs-CRP are not needed for the prediction of coronary heart disease risk, this question requires further studies using data from cohorts (1). Additionally, there are few data regarding hs-CRP values for the older population. We used data from the baseline of the Bambuí Cohort Study, Brazil, to evaluate the distribution of hs-CRP in elderly people from a Brazilian community (3).
The Institutional Review Board approved the study and all subjects gave written informed consent to participate.

\section{Material and Methods}

The baseline survey of the Bambuí Cohort Study comprised residents of Bambuí city (Minas Gerais State, Brazil) aged 60 years or over. Of the 1742 residents, 1606 $(92.2 \%)$ participated in the interview and 1496 (85.9\%) were examined (blood sample, laboratory tests, physical measurements, and electrocardiogram) in the baseline cohort study. The subjects interviewed and examined were similar to the town population aged 60 years or more for all the characteristics evaluated: age, gender, number of residents in the household, marital status, family income, and education (3). Of the subjects examined, 1470 had their hs-

Correspondence: P.G. Vidigal, Departamento de Propedêutica Complementar, Faculdade de Medicina, UFMG, Av. Prof. Alfredo Balena, 190, Sala 403, 301030-100 Belo Horizonte, MG, Brasil. Fax: +55-31-3409-9782. E-mail: pedrovidigal@ufmg.br

Received June 11, 2012. Accepted September 10, 2012. Available online September 28, 2012. Published December $17,2012$. 
CRP measured and were selected for this study; 26 (1.7\%) were not tested because the amount of sample available was insufficient. Blood samples were collected after a 12-h fast and serum samples were stored at $-70^{\circ} \mathrm{C}$. Measurements were made by the hs-CRP immunonephelometric method, Dade-Behring N Latex hs-CRP particle-enhanced immunoassay on an automatic nephelometer (BNII ${ }^{\mathrm{TM}}$, Dade Behring, Germany) traceable to the international reference standard CRM 470 (4). Samples that showed results above the linearity of the test were automatically diluted and remeasured with the same hs-CRP assay. Pre-analytical factors related to blood collection were determined as previously described $(5,6)$. The distribution was assessed by gender for all measured hs-CRP values. The goodness of fit test for normal distribution was evaluated using the KolmogorovSmirnov test. Serum level of hs-CRP was log-transformed to fit a less skewed distribution. The statistical analysis was carried out with the Stata software (7).

\section{Results}

A total of 188 of the individuals selected were excluded from the analysis because they had CRP values of $10 \mathrm{mg} / \mathrm{L}$ or higher. The CRP value (mean $\pm \mathrm{SD}$ ) was $23.8 \pm 18 \mathrm{mg} / \mathrm{L}$ for this group. Thus, the study population consisted of 1286 subjects (501 men and 785 women). Mean age was $69.1 \pm 7.2,68.7 \pm 7.2$ for men and $69.2 \pm 7.3$ for women $(P=0.213)$. The distribution of hs-CRP values did not follow a symmetric bell-shaped curve and more than $50 \%$ of the results were above $3.0 \mathrm{mg} / \mathrm{L}$ for both genders. Table 1 shows the quartiles of hs-CRP values. Mean hs-CRP (logtransformed) was higher in women than in men for all ages, except for individuals older than 80 years (Table 2).

\section{Discussion}

This is the first population-based study to describe hs-CRP values in Latin American elderly subjects. Herbeth et al. (8), in France, used criteria similar to those of the present study and excluded values about $20 \mathrm{mg} / \mathrm{L}$. We chose $10 \mathrm{mg} / \mathrm{L}$ to be the cut-off point, according to literature guidelines that indicate limits for persistently or inexplicably marked elevations in hs-CRP values $(1,9)$. As the distribution of hs-CRP did not follow a symmetric bell-shaped curve, the values of the study population were divided into four equal-sized groups (quartiles). This log-Gaussian distribution is comparable to those observed in other younger and elderly populations $(4,5,8,10,11)$.

A higher mean hs-CRP concentration was observed in all individuals studied compared to gender. previous reports, including a Brazilian study (11-13). Results from the baseline survey of the Helsinki Ageing Study demonstrated association between aging and increase in hs-CRP concentration for elderly men and women (14). It has been suggested that this association is related to the increased production of interleukin-6 (IL-6) associated with aging. CRP levels are predominantly modulated by the hepatic effects of IL-6 $(15,16)$. Differences in the results obtained in different studies may reflect the sociodemographic composition of the studied populations, sample size, and criteria for the selection of participants.

Women were found to have higher hs-CRP levels than men for all ages. The lack of difference in the over- 80 group can be explained by the low number of individuals. Our results agree with those of Araujo et al. (11) who evaluated 684 healthy Brazilian individuals, aged $14-74$ years, and with previous reports from other countries $(5,10,17)$. Other investigators have not observed significant gender differences $(4,18,19)$. Higher hs-CRP values in women may be related to hormone replacement, although the women in our cohort were not undergoing hormone therapy (8). In our study, body mass index and waist circumference were independently correlated with hs-CRP in men and women. In addition, these measures correlated positively with hs-CRP both in men and women (data not shown). The relationship between hs-CRP levels and measurements of obesity may be explained by the finding that adipose tissue

Table 1. Distribution of serum hs-CRP concentration (mg/L) according to

\begin{tabular}{lccc}
\hline & Males $(\mathrm{N}=501)$ & Females $(\mathrm{N}=785)$ & Total $(\mathrm{N}=1286)$ \\
\hline First quartile & $0.17-1.01$ & $0.16-1.48$ & $0.16-1.26$ \\
Second quartile & $1.01-2.22$ & $1.48-2.98$ & $1.26-2.73$ \\
Third quartile & $2.22-4.33$ & $2.98-5.35$ & $2.73-5.04$ \\
Fourth quartile & $4.33-10.0$ & $5.35-10.0$ & $5.04-10.0$ \\
Mean \pm SD & $3.03 \pm 2.50$ & $3.62 \pm 2.58$ & $3.39 \pm 2.56$ \\
\hline
\end{tabular}

$\mathrm{N}=$ number of subjects.

Table 2. Serum concentration of hs-CRP (log-transformed) according to gender and age.

\begin{tabular}{lrlllllr}
\hline \multirow{2}{*}{ Age (years) } & \multicolumn{2}{c}{ Males } & & \multicolumn{2}{c}{ Females } & \multirow{2}{*}{$\mathrm{P}$} \\
\cline { 2 - 3 } & $\mathrm{N}$ & Mean $\pm \mathrm{SD}$ & & $\mathrm{N}$ & Mean \pm SD & \\
\hline $60-69$ & 306 & $0.7 \pm 0.9$ & & 465 & $1.0 \pm 0.9$ & $<0.001$ \\
$70-79$ & 145 & $0.7 \pm 1.0$ & & 237 & $0.9 \pm 0.9$ & 0.022 \\
$80+$ & 50 & $0.8 \pm 1.0$ & & 83 & $0.8 \pm 0.9$ & 0.877 \\
Total & 501 & $0.7 \pm 0.9$ & & 785 & $1.0 \pm 0.9$ & $<0.001$ \\
\hline
\end{tabular}

$\mathrm{N}=$ number of subjects. The Student $t$-test was used for statistical analysis. 
releases IL-6 in vivo, being implicated as a major source of circulating IL-6 (20).

Many clinical and laboratory variables appear to influence the concentration of hs-CRP according to gender (11-14). Our study shows that significant gender differences in hs-CRP distribution exist in the elderly population and suggests that gender-specific cut-off points for hs-CRP should be clinically used in assessing the risk of future

\section{References}

1. Myers GL, Christenson RH, Cushman M, Ballantyne CM, Cooper GR, Pfeiffer CM, et al. National Academy of Clinical Biochemistry Laboratory Medicine Practice guidelines: emerging biomarkers for primary prevention of cardiovascular disease. Clin Chem 2009; 55: 378-384.

2. Ridker PM, Hennekens $\mathrm{CH}$, Buring JE, Rifai N. C-reactive protein and other markers of inflammation in the prediction of cardiovascular disease in women. N Engl J Med 2000; 342: 836-843.

3. Costa MF, Uchoa E, Guerra HL, Firmo JO, Vidigal PG, Barreto SM. The Bambuí health and ageing study (BHAS): methodological approach and preliminary results of a population-based cohort study of the elderly in Brazil. Rev Saúde Pública 2000; 34: 126-135.

4. Erlandsen EJ, Randers E. Reference interval for serum C-reactive protein in healthy blood donors using the Dade Behring N Latex CRP mono assay. Scand J Clin Lab Invest 2000; 60: 37-43.

5. Chenillot O, Henny J, Steinmetz J, Herbeth B, Wagner C Siest G. High sensitivity $\mathrm{C}$-reactive protein: biological variations and reference limits. Clin Chem Lab Med 2000; 38: 1003-1011.

6. Ledue TB, Rifai N. Preanalytic and analytic sources of variations in C-reactive protein measurement: implications for cardiovascular disease risk assessment. Clin Chem 2003; 49: 1258-1271.

7. Stata. Data analysis and Statistical Software. Release 5.0. [Computer program]. College Station: Stata Corporation; 1997.

8. Herbeth B, Siest G, Henny J. High sensitivity C-reactive protein (CRP) reference intervals in the elderly. Clin Chem Lab Med 2001; 39: 1169-1170.

9. Gabay C, Kushner I. Acute-phase proteins and other systemic responses to inflammation. N Engl J Med 1999; 340: 448-454.

10. Wener MH, Daum PR, McQuillan GM. The influence of age, sex, and race on the upper reference limit of serum C-reactive protein concentration. J Rheumatol 2000; 27: 2351-2359. cardiovascular events.

\section{Acknowledgments}

This study could not be carried out without the cooperation of the population of Bambuí. Research supported by FAPEMIG (\#APQ-01534-08).

11. Araujo F, Pereira AC, Latorre MR, Krieger JE, Mansur AJ. High-sensitivity C-reactive protein concentration in a healthy Brazilian population. Int J Cardiol 2004; 97: 433-438.

12. Ridker PM, Buring JE, Shih J, Matias M, Hennekens $\mathrm{CH}$. Prospective study of C-reactive protein and the risk of future cardiovascular events among apparently healthy women. Circulation 1998; 98: 731-733.

13. Wong ND, Pio J, Valencia R, Thakal G. Distribution of Creactive protein and its relation to risk factors and coronary heart disease risk estimation in the National Health and Nutrition Examination Survey (NHANES) III. Prev Cardiol 2001; 4: 109-114.

14. Strandberg TE, Tilvis RS. C-reactive protein, cardiovascular risk factors, and mortality in a prospective study in the elderly. Arterioscler Thromb Vasc Biol 2000; 20: 1057-1060.

15. Hager K, Machein U, Krieger S, Platt D, Seefried G, Bauer J. Interleukin- 6 and selected plasma proteins in healthy persons of different ages. Neurobiol Aging 1994; 15: 771-772.

16. Heinrich PC, Castell JV, Andus T. Interleukin- 6 and the acute phase response. Biochem J 1990; 265: 621-636.

17. McConnell JP, Branum EL, Ballman KV, Lagerstedt SA, Katzmann JA, Jaffe AS. Gender differences in C-reactive protein concentrations - confirmation with two sensitive methods. Clin Chem Lab Med 2002; 40: 56-59.

18. Wood WG, Ludemann J, Mitusch R, Heinrich J, Maass $\mathrm{R}$, Frick $\mathrm{U}$. Evaluation of a sensitive immunoluminometric assay for the determination of C-reactive protein (CRP) in serum and plasma and the establishment of reference ranges for different groups of subjects. Clin Lab 2000; 46: 131-140.

19. Rifai N, Ridker PM. Population distributions of C-reactive protein in apparently healthy men and women in the United States: implication for clinical interpretation. Clin Chem 2003; 49: 666-669.

20. Yudkin JS, Stehouwer CD, Emeis JJ, Coppack SW. C-reactive protein in healthy subjects: associations with obesity, insulin resistance, and endothelial dysfunction: a potential role for cytokines originating from adipose tissue? Arterioscler Thromb Vasc Biol 1999; 19: 972-978. 